Provided for non-commercial research and education use. Not for reproduction, distribution or commercial use.

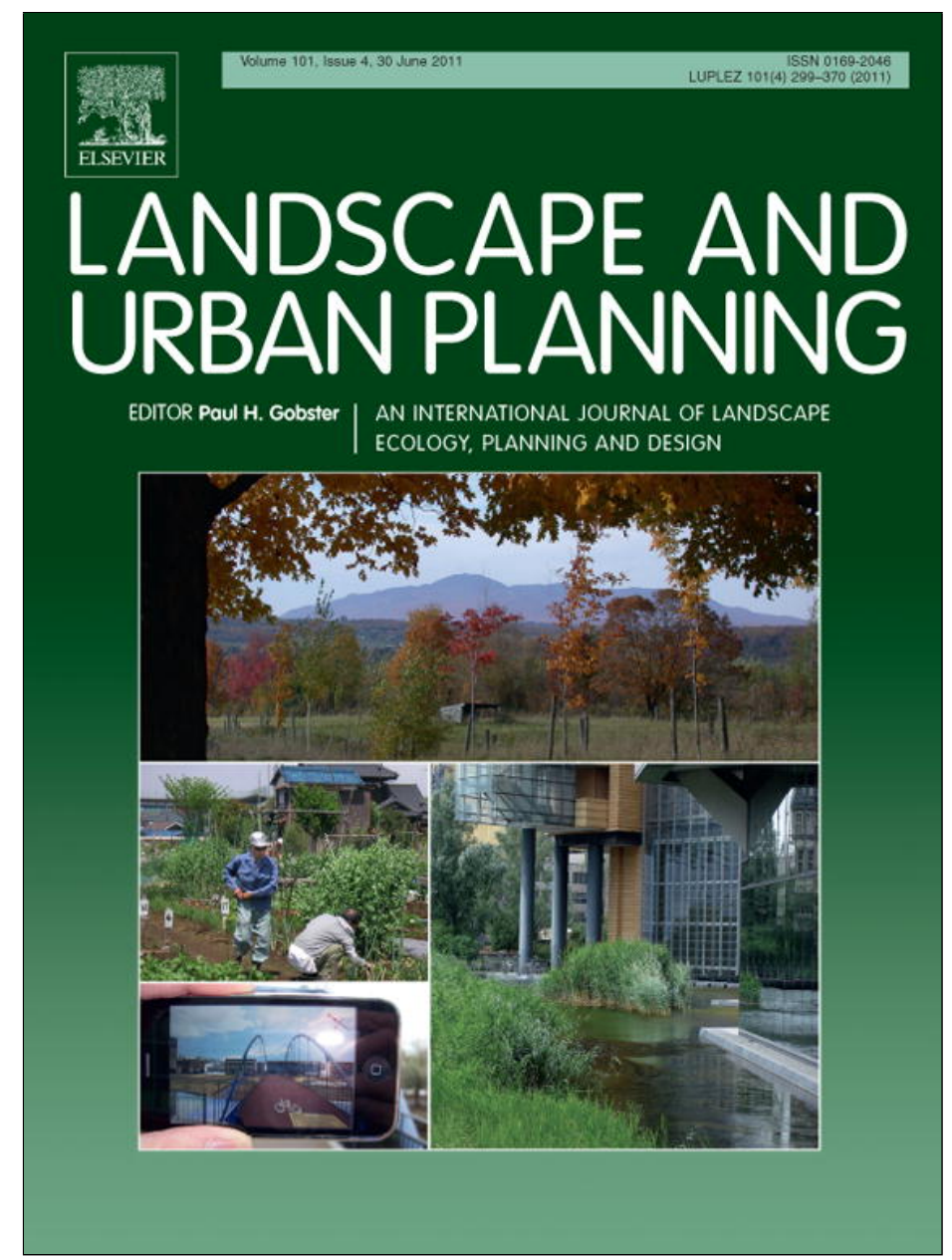

This article appeared in a journal published by Elsevier. The attached copy is furnished to the author for internal non-commercial research and education use, including for instruction at the authors institution and sharing with colleagues.

Other uses, including reproduction and distribution, or selling or licensing copies, or posting to personal, institutional or third party websites are prohibited.

In most cases authors are permitted to post their version of the article (e.g. in Word or Tex form) to their personal website or institutional repository. Authors requiring further information regarding Elsevier's archiving and manuscript policies are encouraged to visit:

http://www.elsevier.com/copyright 


\title{
Place meanings and desired management outcomes
}

\author{
Jordan W. Smith ${ }^{\mathrm{a}, *}$, Mae A. Davenport ${ }^{\mathrm{b}}$, Dorothy H. Anderson ${ }^{\mathrm{a}}$, Jessica E. Leahy ${ }^{\mathrm{c}}$ \\ a North Carolina State University, Box 8004 Biltmore Hall (NCSU), Raleigh, NC 27695-8004, USA \\ ${ }^{\mathrm{b}}$ University of Minnesota, 115 Green Hall (University of Minnesota), 1530 Cleveland Ave. N., St. Paul, MN 55108-6112, USA \\ ' University of Maine, 219 Nutting Hall (University of Maine), Orono, ME 04469-5755, USA
}

\section{A R T I C L E I N F O}

Article history:

Received 21 July 2010

Received in revised form 1 March 2011

Accepted 8 March 2011

Available online 8 April 2011

\section{Keywords:}

Place meanings

Desired management outcomes

Community benefits

\begin{abstract}
A B S T R A C T
Federal land management agencies and social scientists have been attempting to understand place meanings and the perceptions of resource users for decades. In this research, we suggest that understanding the relationships between the meanings individuals ascribe to managed landscapes and those individuals' preferences for management outcomes have become increasingly important. The processes of devolution and globalization have simultaneously increased the need for locally informed collaborative management and increased the importance of local 'place'. Following the cognitive perspective on place, we examine how individuals' place meanings affect their desired management outcomes. Data come from a questionnaire administered to residents living near three U.S. Army Corps of Engineers managed projects within Illinois' Kaskaskia River Watershed. Confirmatory factor analysis is employed to validate a sevendimensional scale of place meanings and a six-dimensional scale of desired management outcomes. Subsequent structural equation modeling revealed that desired management outcomes were significantly influenced by place meanings (12 significant relationships found). Most notably, the analysis revealed that believing the managed resource area contributed to the local community's identity significantly and positively influenced all of the possible management outcomes. The connection between resource management and community identity matters. Other findings reveal individuals attached a variety of meanings to the resource, and that these meanings can affect desired management preferences in distinct and potentially conflicting ways. In sum, our findings begin to unravel some of the complexities between the various meanings attached to managed landscapes and their affect on desired management outcomes.
\end{abstract}

(c) 2011 Elsevier B.V. All rights reserved.

\section{Introduction}

The primary objective of natural resource planning, according to Williams and Stewart (1998), is to develop a shared future sense of place by describing, contesting, and negotiating current place meanings. To achieve this objective, resource management needs at least two pieces of information:

1. meanings individuals ascribe to managed landscapes;

2. desires and needs of current and potential resource users.

With respect to the first, the meanings individuals endow upon specific places are diverse and often in competition with one another. Local retailers may value a managed resource area because it attracts tourism revenues and increases sales receipts. Conversely,

\footnotetext{
* Corresponding author. Tel.: +1 4358306294.

E-mail addresses: jwsmit12@ncsu.edu (J.W. Smith), mdaven@umn.edu (M.A. Davenport), dorothy_anderson@ncsu.edu (D.H. Anderson), jessica.leahy@maine.edu (J.E. Leahy).
}

a long-term resident living near the same resource may value it because of the strong social bonds with family and friends they have formed there in the past. Through an understanding of the meanings individuals ascribe to managed resource areas, management can better anticipate those individuals' responses to management actions. For example, previous research has found place meanings to be reliable predictors of individuals' sensitivity to environmental impacts (Stedman, 2003; White, Virden, \& van Riper, 2008; Williams, Patterson, Roggenbuck, \& Watson, 1992), and support for resource use fees (Kyle, Absher, \& Graefe, 2003).

Simply documenting and being aware of the meanings individuals attach to managed landscapes, however, is of limited use without connecting those meanings to individual's desired management actions and outputs. It is unlikely for resource planners to "develop a shared future sense of place", as Williams and Stewart suggest (p. 23), without also understanding how specific types of meanings affect the desired outcomes that individuals would like to see the resource managed for. Equipped with an understanding of the complex bonds individuals form with natural landscapes and how those bonds affect beliefs about how the resource should be managed, resource planners can be more proactive in developing 
socially acceptable management strategies that ideally lead to a shared sense of place.

The objective of this research is to examine how various place meanings affect desired management outcomes. The relationships between place meanings and desired outcomes of resource management have become increasingly important over the past four decades because of two distinct processes forcing attention on local concerns: devolution and globalization, the latter has increased the need for locally informed collaborative planning and management while the former has increased the importance of local place.

\subsection{Devolution and (re)focusing on the local}

Federal land management agencies within the United States have been attempting to understand place meanings and the perceptions of resource users since 1946 when Congress passed the Administrative Procedures Act which established a minimum standard for public involvement in decision making (Koontz et al., 2004). Some policy makers and citizens were concerned that the establishment of U.S. President Franklin Delano Roosevelt's New Deal programs and the subsequent expansion of land management agencies would marginalize the public's opportunity to be heard in management decisions. Participation in management decisions was initially minimal but expanded rapidly as the public's general concern for the environment increased in the 1960s and 1970s (Golden, 1998; Dunlap \& Mertig, 1991). More explicit public policy (e.g., the Economic Opportunity Act of 1964 and the National Environmental Policy Act of 1969) soon followed, which required direct consideration of resource users' needs and desires when making resource allocation decisions.

At the same time U.S. citizens, enmasse, were able to voice their opinions about resource management, public skepticism was growing concerning the federal government's ability to meet its new mandates and facilitate the needs of local community members most likely to be affected by management's decisions (Koontz et al., 2004). The ability of rural community members, in particular, to voice their opinions may have been limited given the poorer social and economic conditions which frequently characterize the places in which they live (Hunter, Boardman, \& Saint Onge, 2005). Growing mistrust in the ability of federal agencies to meet their policy objectives soon led to widespread public support for decision making authority to be transferred from the federal level to the state and local levels. This process of devolution has characterized much public policy since the 1970s (Sharp \& Parisi, 2003; Warner, 2003).

Devolution in land management primarily has meant two things for resource planners: First, resource allocation decisions increasingly become the responsibility of local field offices or ranger districts. As a result, local social, economic, and ecological contexts play a much larger role in resource management. Second, no longer can planners rely on 'technocratic' or 'scientific' authority to enforce decisions. Rather, new management approaches, such as collaborative natural resource management and ecosystem management, are needed not only to conserve the resources themselves, but also to do so in a socially acceptable and desirable manner. In short, the outcomes for which local communities want to see produced, in terms of the resource and its management, become increasingly important.

\subsection{Desired outcomes are informed by relationships with place}

Devolution has pushed management decision capabilities down to more local levels and made resource planners consider the needs and desires of local individuals who live near, and in many cases depend upon, the landscapes they are responsible for managing. It benefits the planner to understand what drives local needs and desires. What are the outcomes that local community members want to see emerge from the resource and its management? Finally, what drives those desired outcomes?

In this paper, we suggest a key driver of desired outcomes is the distinct type of meanings which individuals ascribe to the resource. Following the cognitive perspective on place launched within human geography (Relph, 1976; Tuan, 1974) and environmental psychology (Canter, 1977; Moore, 1976), we suggest the desired outcomes for which individuals would like to see a landscape managed, are driven by how the human mind processes information about the geographic setting (Burnett, 1976). The human mind categorizes and discriminates information about the landscape according to cognitive strategies, personality, and social and cultural contexts. Individuals imbue significance and importance to geographic settings due to both the characteristics of the setting itself (i.e., place as location), and as the processes of interacting with that setting (i.e., a developed sense of place). 'Place' becomes both a product of physical location and the interactions, which are often experiences with others, with the location (Agnew \& Duncan, 1989; Kruger, 2001). The categorization and discrimination process influences the value individuals ascribe to the space as well as their attitudes about how it should be managed (Cheng, Kruger, \& Daniels, 2003; Kruger, 2008; Kruger \& Williams, 2007).

Previous research has adopted a similar perspective, perhaps implicitly, and examined how the meanings individuals ascribe to a specific setting influence their preferences for management actions or behaviors. For example, in a study of whitewater recreationists on the South Fork of the American River in California, Bricker (1998) found that individuals who believed their personal identity was shaped by the resource held significantly different views regarding desired management actions compared to individuals who believed the resource only provided the functional setting required for their desired activity. Vogt and Williams (1999) also found variations in management preferences relative to specific types of place meanings. More recent evidence continues to support the assumption that attitudes toward resource management are shaped by the meanings individuals ascribe to the resources in question (Kruger \& Jakes, 2003). For example, Kyle et al. (2003) found recreationists who identified strongly with a scenic area in California's Inyo National Forest were more likely to support spending fee revenues to manage the area.

The growing body of literature concerning place meanings and desired management outcomes supports the assumptions behind the cognitive perspective on place-place meanings affect attitudes and values toward resource management. This assumption, coupled with the trend of devolution in resource policy making and planning, has had large implications for public land managers today. It has become increasingly important for planners to understand how resource users would like to see the landscape managed and to understand the meanings which drive those preferences. As Cheng et al. (2003) suggested, 'place' has become an integrating concept in natural resource management.

\subsection{Globalization and the increased importance of place and local society}

While devolution has gradually transformed public land management to more local levels, a second process-globalization-has also increased the need to understand the relationships between place meanings and desired management outcomes. Many of the same processes behind devolution (e.g., the expansion of neoliberal economic policies and the reduction of trade barriers during the 1980s) have also led to the rapid spatial and temporal compression of social interaction (Boden \& Molotch, 1994). This process of globalization has led to the social homogenization of tastes (Meyer, Boli, Thomas, \& Ramirez, 1997) and simultaneously exacerbated social inequalities (Lobao, 2004; Tickamyer, 2000). As globalization has 
expanded access to new peoples and places, it has also uprooted social meanings and identities from specific spaces (Harvey, 1996).

At one time community was defined by the completeness of a local society-the relatively comprehensive network of associations for meeting common needs and expressing common interests (Wilkinson, 1991). Local cultures and societies adapted to meet the environmental constraints of place. As a result, local identities became strongly tied to those places (Williams, 2002). Modern communities, however, are liberated from the constraints of local spaces (Harvey, 1993). As a result, the role of local landscapes in shaping individual identity has shifted. Individuals' experiences of mobility, home, and ultimately the spatial construction of their identities-the sense of who we are and where we belong-have changed. The meanings attached to managed landscapes are now more complex and not solely defined by local influences.

Perhaps counterintuitively, globalization has also increased the importance of the local in individuals' lives (Mander \& Goldsmith, 1996). Under the expansion of global capital what used to be "taken-for-granted, subconscious meanings of a place come to the surface and seem threatened by nearly every proposed change to the local landscape" (Williams \& Stewart, 1998, p. 21). For landscape managers and planners as well as social scientists, this means understanding 'place' has become increasingly important (Mander \& Goldsmith, 1996). And we suggest understanding how the meanings individuals ascribe to managed landscapes affect the outcomes they would like to see that landscape managed for are of prime importance.

\section{The forms of place meanings}

Place is defined as physical space imbued with meaning (Low \& Altman, 1992). The meanings associated with physical space can encompass instrumental or utilitarian values as well as intangible values such as belonging, attachment, beauty, and spirituality. These place meanings are contingent upon individuals' relationship with the space and are not easily categorized (Cheng et al., 2003). As a result, a large body of literature has emerged to attempt to identify the distinct, and empirically valid, dimensions of place meanings (e.g., Kyle, Graefe, \& Manning, 2005; Shamai, 1991; Stedman, 2003; Williams \& Vaske, 2003). Different conceptualizations of place meanings often vary by their disciplinary roots, and consequently emphasize different aspects of individuals' relationships with space (see Trentelman, 2009). For example, some sociologists have asserted that 'place' is a social construction defined by a group's position in the processes of production and consumption (Greider \& Garkovich, 1994). This research adopts the cognitive perspective, most frequently associated with psychology and social psychology, and claims the meanings associated with place shape attitudes and beliefs about how landscapes should be managed.

The dimensions of place meaning which we examine in this study were generated from the existing literature and previous analysis of qualitative data generated from interviews with residents living near managed resource areas in the Midwestern United States (Davenport, 2003, 2006; Davenport \& Anderson, 2005). Specifically, seven place meaning dimensions are examined: individual identity, family identity, self-efficacy, self-expression, community identity, economic meaning, and ecological meaning. Each type of meaning is a relatively distinct way that individuals ascribe importance or significance to the landscape and how they value it.

Individual identity represents the extent to which individuals believe the landscape informs their self-identity (Proshansky, Fabian, \& Kaminoff, 1995). Given self-identity provides purpose for one's life, a high level of individual place identity reflects a life guided by the presence and maintenance of the managed landscape.

Family identity extends the concept of individual place identity and represents the extent to which the landscape defines one's belief about their family's unique identity (Kruger $\&$ Shannon, 2000). Strong social bonds and memories formed through the presence of the resource are examples of meanings that reflect the family identity construct.

Self-efficacy, which is both theoretically and empirically related to 'place dependence' in previous research (see Williams et al. (1992) and Williams and Vaske (2003) respectively), represents the meanings associated with doing things or spending time in the resource area. The functional dependence of recreation settings for specific types of activities is the most apparent example of self-efficacy meanings.

Self-expression represents meanings associated with how the resource provides opportunities for individuals to convey their true self. Self-expression is a related but conceptually distinct concept from individual place identity. The former involves action and the communication of one's self while the later is limited to the defining of that self.

Community identity meanings represent beliefs about the extent to which the managed landscape contributes to local culture, character, and identity. Community meanings are similar to family identity in that they represent beliefs about one's social group; they differ in that community meanings attempt to gauge the extent to which the landscape contributes to the aggregate local identity.

The final two dimensions of place meanings are economic meanings and ecological meanings. Economic meanings represent beliefs about how the resource area contributes to the community's economic health. Concurrently, ecological meanings represent beliefs about how the resource functions to preserve community open space and ecosystem health. Again, each of these seven types of place meaning is a relatively distinct way that individuals can make sense of the landscape and ascribe meaning and significance to it.

\section{Desired outcomes from resource management}

Literally thousands of potential desired outcomes can be identified for a managed landscape. Despite the plethora of potential management actions, previous research has identified six broad categories of outcomes that are produced by nearly all managed landscapes and that can be emphasized through the actions of resource management and planning efforts. These six broad categories of outcomes are: ecological, economic, lifestyle, quality of life, sense of physical space, and social solidarity (Smith, Anderson, Davenport, \& Leahy, 2010). Ecological outcomes include watershed protection and wildlife habitat. Economic outcomes include the continued production of jobs, tourism revenues, and other capital flows directly attributable to the resource area and its management. Lifestyle outcomes include resource area contributions to a socially desirable lifestyle for residents. For example, the continued provision of recreation opportunities and the ability for local community members to maintain outdoor oriented lifestyles are examples of explicit management objectives focused on contributing to local lifestyles. Lifestyle outcomes are explicitly behavioral, while more general outcomes are included in the next dimension, quality of life. Quality of life outcomes include ways the managed resource area contributes to an individual's satisfaction with the place. While quality of life outcomes are arguably the most nebulous outcomes which management can explicitly produce, they are now well established within nearly all land management agencies' planning guidelines (e.g., U.S. Department of Agriculture, 2010; U.S. 


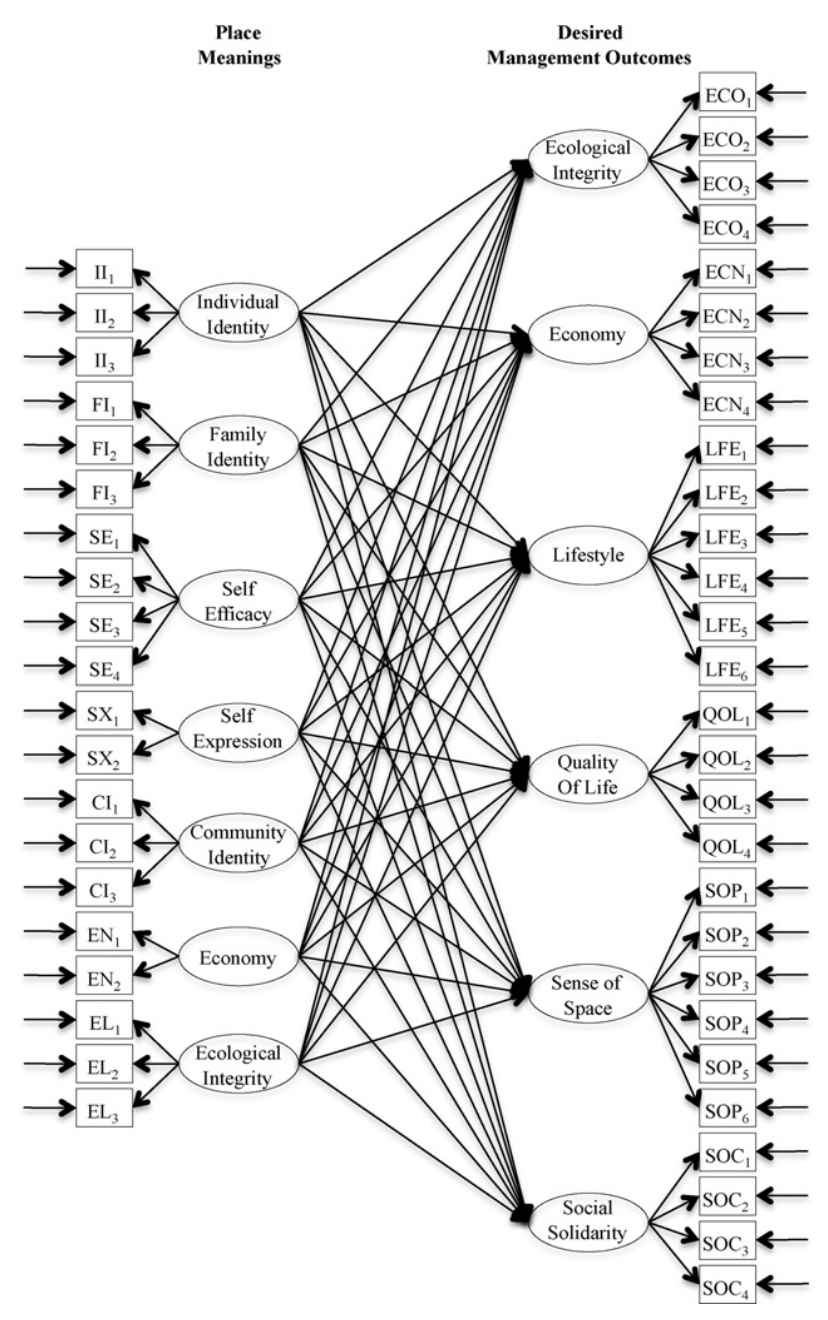

Fig. 1. Hypothesized model of place meanings and desired management outcomes.

Department of the Interior, 2011). Sense of physical space outcomes represents the role managed resource areas play in the conservation of a unique community identity. Many resource-associated communities retain distinctive architectures and 'small-town feelings' largely because of the landscapes in which they are embedded. Understanding how place meanings influence individuals' desire to see these characteristics preserved can play a role in the extent to which landscape planners focus their efforts on collaborative planning with local governments outside land management area boundaries. Finally, social solidarity outcomes represent resource management fostered feelings of community and local pride. Again, each of these six outcome categories can be emphasized through the actions of resource management and planning efforts.

\section{Materials and methods}

The objective of this research is to examine how various place meanings affect management outcomes desired by residents living proximate to federally managed resource areas. The hypotheses being tested involve the presence of a relationship between each of the seven hypothesized place meanings and each of the six possible management outcomes. These relationships are illustrated in Fig. 1.

\subsection{Measures}

Based upon the existing literature, we developed a 20-item scale to assess place meanings. Place meanings were measured using a 20-item scale (Table 1 ) developed in previous place meanings research (Davenport, Baker, Leahy, \& Anderson, 2010). Individuals were asked to indicate their level of agreement with each of the scale items. A seven-point Likert-style scale was used which ranged from (1) strongly agree to (7) strongly disagree. Between two and four scale-items were used to measure each of the seven types of place meanings discussed above.

Scale-item development to assess desired management outcomes occurred through two distinct phases. First, as part of a larger study, interviews were conducted with community members and resource management personnel in areas surrounding six federally managed resource areas in the United States. The qualitative data collected through these interviews as well as the existing literature on desired management outcomes led to the development of the 28-item scale seen in Table 1 (see Anderson, Davenport, Leahy, \& Stein, 2008 for more detail). Individuals were asked to indicate how important it was for them that the resource area produces each scale-item. A five-point Likert-style scale was used which ranged from (1) very unimportant to (5) very important.

\subsection{Study areas}

Data for this study were collected from a random sample of community members living within Kaskaskia River Watershed. The watershed is located in central and southern Illinois and includes three projects (Lake Shelbyville, Carlyle Lake, and the Kaskaskia River Navigation Project) managed by the U.S. Army Corps of Engineers. Previous research within the watershed has illustrated an interesting history of interactions between resource managers and local residents (Leahy \& Anderson, 2010). The study area represents a regional working landscape in that it includes not only recreation settings, which are common in the place meanings literature, but also the spaces of daily life, where work, family, and community become engaged as a local society (Wilkinson, 1991).

\subsection{Data collection}

Our representative population includes all households within 15 miles of each of the three projects. The sample was generated through tax records and telephone listings that included an address. A sample of 533 households was drawn from around each lake (1599 total). These samples were administered a mail-back questionnaire according to Dillman's Tailored Design Method (2007). A total of 65 questionnaires were undeliverable to the Lake Shelbyville sample and 213 were returned completed for a $46 \%$ response rate. A total of 41 questionnaires were undeliverable to the Carlyle Lake sample and 233 were returned completed for a $45 \%$ response rate. Finally, a total of 25 were undeliverable to the Navigation Project sample and 201 were returned completed for a $40 \%$ response rate. Nonresponse bias was checked using the extrapolation method of successive survey waves (Armstrong \& Overton, 1977). Comparisons of the first and last waves' respondents on gender, education, income, and age showed no differences in the Lake Shelbyville and Navigation Project samples. In the Carlyle Lake sample, first wave respondents differed from third wave respondents on their level of educational attainment.

\subsection{Data analysis}

We conducted the analysis in four phases. First, we pooled the three samples and determined the fit of the measurement 
Table 1

Item descriptives, internal consistencies, and factor loadings.

\begin{tabular}{|c|c|c|c|c|c|}
\hline Dimension and statements & $M$ & $S D$ & $\alpha$ & $\alpha$ if deleted & Factor loading \\
\hline \multicolumn{6}{|l|}{ Panel A: place meanings scale } \\
\hline Individual identity & & & 0.87 & & \\
\hline I am very attached to this lake & 5.56 & 1.48 & & 0.86 & 0.75 \\
\hline I feel this lake is a part of me & 4.71 & 1.64 & & 0.79 & 0.83 \\
\hline I identify strongly with this lake & 4.61 & 1.64 & & 0.78 & 0.84 \\
\hline Family identity & & & 0.87 & & \\
\hline I feel a sense of pride in my heritage when I am there & 4.64 & 1.62 & & 0.83 & 0.79 \\
\hline This lake is a special place for my family & 5.01 & 1.67 & & 0.77 & 0.85 \\
\hline Many important family memories are tied to this lake & 4.94 & 1.82 & & 0.84 & 0.79 \\
\hline Self efficacy & & & 0.88 & & \\
\hline This lake is best for what I like to do & 4.89 & 1.64 & & 0.88 & 0.72 \\
\hline I get more satisfaction out of visiting this lake than any other & 4.38 & 1.82 & & 0.84 & 0.84 \\
\hline Doing what I do at this lake is more important to me than doing it in any other place & 4.25 & 1.76 & & 0.85 & 0.82 \\
\hline I wouldn't substitute any other area for doing the types of things I do at this lake & 4.10 & 1.81 & & 0.84 & 0.83 \\
\hline Self expression & & & 0.85 & & \\
\hline I feel that I can really be myself at this lake & 5.18 & 1.58 & & - & 0.81 \\
\hline When I am there others see me the way I want them to see me & 4.87 & 1.53 & & - & 0.81 \\
\hline Community identity & & & 0.86 & & \\
\hline This lake contributes to the character of my community & 5.45 & 1.57 & & 0.78 & 0.83 \\
\hline My community's history is strongly tied up in the history of this lake & 5.06 & 1.71 & & 0.81 & 0.79 \\
\hline This lake helped put my community on the map & 5.49 & 1.78 & & 0.83 & 0.77 \\
\hline Economy & & & 0.74 & & \\
\hline My community's economy depends on this lake & 4.94 & 1.92 & & - & 0.68 \\
\hline Local economy depends on this lake & 4.35 & 2.00 & & - & 0.68 \\
\hline Ecological integrity & & & 0.80 & & \\
\hline This lake is important in protecting the landscape from development & 5.00 & 1.85 & & 0.80 & 0.66 \\
\hline This lake is important in providing habitat for wildlife & 5.99 & 1.49 & & 0.68 & 0.79 \\
\hline This lake is important in protecting water quality & 5.41 & 1.66 & & 0.70 & 0.76 \\
\hline \multicolumn{6}{|l|}{ Panel B: desired outcomes scale } \\
\hline Ecological & & & 0.92 & & \\
\hline Improved soil, water, and air quality & 4.25 & 0.88 & & 0.92 & 0.77 \\
\hline A sense of security that the natural environment will not be lost & 4.23 & 0.87 & & 0.88 & 0.88 \\
\hline A place to conserve various natural and unique ecosystems & 4.10 & 0.90 & & 0.89 & 0.86 \\
\hline Knowing conserved natural resources exists for future generations & 4.31 & 0.85 & & 0.88 & 0.90 \\
\hline Economy & & & 0.93 & & \\
\hline Having a more stable economy within my community & 4.24 & 0.88 & & 0.91 & 0.88 \\
\hline Increased job opportunities within my community & 4.31 & 0.89 & & 0.89 & 0.90 \\
\hline Attracting tourism dollars to my community & 4.24 & 0.92 & & 0.93 & 0.79 \\
\hline Having a more stable economy for the surrounding region & 4.25 & 0.87 & & 0.89 & 0.90 \\
\hline Lifestyle (behavioral) & & & 0.88 & & \\
\hline More community involvement in recreation & 3.84 & 0.85 & & 0.87 & 0.65 \\
\hline A greater concern for the natural environmental among residents & 4.11 & 0.81 & & 0.86 & 0.77 \\
\hline Increased knowledge about the area's cultural resources & 3.89 & 0.86 & & 0.85 & 0.79 \\
\hline A chance for local people to maintain an outdoor-oriented lifestyle & 4.11 & 0.84 & & 0.86 & 0.72 \\
\hline Opportunities for residents to grow spiritually & 3.80 & 1.02 & & 0.87 & 0.70 \\
\hline Opportunities for exercise that improve local people's health & 4.08 & 0.88 & & 0.84 & 0.84 \\
\hline Quality of life (general) & & & 0.86 & & \\
\hline Heightened sense of community satisfaction & 3.85 & 0.85 & & 0.86 & 0.67 \\
\hline Living in a healthy environment & 4.41 & 0.82 & & 0.81 & 0.80 \\
\hline Providing a good quality of life & 4.22 & 0.85 & & 0.79 & 0.85 \\
\hline A higher quality of life & 4.29 & 0.81 & & 0.82 & 0.76 \\
\hline Sense of physical space & & & 0.89 & & \\
\hline A greater ability to preserve small-town feeling of your community & 3.97 & 0.91 & & 0.88 & 0.68 \\
\hline Better maintenance of community infrastructure & 3.90 & 0.92 & & 0.87 & 0.79 \\
\hline Greater retention of community's distinctive architecture & 3.58 & 0.97 & & 0.88 & 0.73 \\
\hline Improved care for community aesthetics & 3.78 & 0.86 & & 0.86 & 0.85 \\
\hline Feeling that your community is a special place to live & 4.13 & 0.90 & & 0.86 & 0.82 \\
\hline Having a better sense of my place within my community & 3.78 & 0.89 & & 0.88 & 0.73 \\
\hline Social solidarity & & & 0.88 & & \\
\hline A stronger sense of community togetherness or cohesion & 3.77 & 0.90 & & 0.84 & 0.84 \\
\hline A stronger sense of family bonds within the community & 3.77 & 0.91 & & 0.84 & 0.83 \\
\hline A natural setting in which your community takes great pride & 4.13 & 0.84 & & 0.86 & 0.76 \\
\hline A feeling of community pride & 3.99 & 0.87 & & 0.86 & 0.77 \\
\hline
\end{tabular}

model using confirmatory factor analysis. Second, to assess the reliability of the model, we tested for measurement and covariance invariance across the three samples. Third, we estimated the structural model by including model paths from the place meaning constructs to the desired management outcome constructs. Finally, we further examined the reliability of the structural model by testing for measurement and structural invariance across the samples.

\subsubsection{Confirmatory factor analysis}

We pooled all three samples together to determine the best fitting measurement model. Model fit was based on the following fit indices: the maximum likelihood $\chi^{2}$, the relative $\chi^{2}\left(\chi^{2} / d f\right)$, the root mean-square error of approximation (RMSEA), the Akaike Information Criteria (AIC), the expected cross-validation index (ECVI), the comparative fit index (CFI), and the incremental fit index (IFI). The maximum likelihood $\chi^{2}$ is a statistic of discrepancy between 
the sample and model covariance matrices; larger values indicate greater discrepancies and therefore poorer model fit. Because the maximum likelihood $\chi^{2}$ is sensitive to large sample sizes, the relative $\chi^{2}$ divides by the model's total number of degrees of freedom. Kline (2005) suggests a relative $\chi^{2}$ value of three or less indicates acceptable model fit. However, other authors suggest values of up to five may be acceptable (Schumacker \& Lomax, 2004). The RMSEA assesses model fit while penalizing model complexity (large $d f$ ). RMSEA values of 0.06-0.08 are acceptable if the upper bound of the RMSEAs confidence interval is below 0.10 (Hu \& Bentler, 1999). The AIC is another measure which penalizes model complexity and is most frequently utilized to compare models with different numbers of latent variables (i.e., non-nested versus nested models). Lower AIC values represent a better model fit. The ECVI is useful for comparing non-nested models across samples, hence its name. Like various other fit indices, the ECVI tests for discrepancies between the sample and model covariance matrices; and like the AIC, lower ECVI values represent a better model fit. Both the CFI and the IFI indicate the extent to which the model fits better than a null model with uncorrelated indicator variables. The values of the CFI and the IFI range from 0 to 1 with values nearer to 1 indicating a better fit.

\subsubsection{Invariance testing}

The next stage of the analysis involved separating the samples and using multi-group analysis to test for measurement and covariance invariance. Invariance testing can lend support for the reliability and generalizability of the best-fitting measurement model. Measurement invariance is tested by constraining model configuration, measurement weights, and intercepts to be equal across both samples (Kline, 2005). The purpose of examining measurement invariance is to discern if the scale-items measure the same latent constructs across samples. Similarly, covariance invariance is tested by adding the additional constraint of equal factor variances and covariances across samples. Covariance invariance discerns whether the relationships between latent constructs are similar across samples. Both measurement and covariance invariance are determined by comparing model fit indices between a baseline configural model and the subsequent models with constrained parameters. Invariance is supported if the change in CFI between models is less than 0.01 (Cheung \& Rensvold, 2002).

\subsubsection{Structural model assessment}

After discerning whether the measurement model provided an adequate fit to the data, we introduced structural paths from the place meaning constructs to the desired outcome constructs. First, we assessed the fit of the structural model with the pooled dataset. The fit of the structural model was assessed using the same indices and criteria as used for the measurement model. Next, we tested for invariance across samples. Measurement and covariance invariance were tested and we also tested for structural invariance. Structural invariance was tested by constraining the model's structural paths to be equal across the samples; it tests for the discrepancies in the predictive relationships (structural paths) between latent constructs. When testing for structural invariance we compared fit indices of the restricted model against the fit indices of the configural model and values less than 0.01 indicate invariance.

\section{Results}

\subsection{Descriptive statistics}

Descriptive statistics of scale-items for the entire sample are shown in Table 1. Statistics for each of the sub-samples as well as ANOVA results computed across samples are shown in the
Appendix. Initial analysis of place meaning scale-item means illustrates that residents living within the watershed attach a diverse array of meanings to the managed resource areas. All item means were above the scale's neutral value of 4 . The strongest meanings were associated with how the study sites contributed to community identity $(M=5.06-5.49)$ and the area's environmental conditions $(M=5.00-5.99)$. Conversely, the weakest meanings associated with the study sites revolved around their contribution to the local economy ( $M=4.35-4.94)$ and their functional ability to support desired activities (self efficacy, $M=4.10-4.89$ ). The reliability of scale-items relative to their hypothesized dimensions was more than adequate $(\alpha \geq 0.74)$. Also, no single item reduced the internal reliability of each hypothesized dimension (Table 1 Column 4).

Analysis of the desired outcomes scale-item means shows residents living within the watershed would ideally like management to focus on and produce all six potential outcomes. All item means were notably above the scale's neutral value of 2.5 and the standard deviations are relatively small, indicating consistent and high preferences for each of the items. Again, the reliability of scale-items relative to their hypothesized dimensions was acceptable $(\alpha \geq 0.86)$ and no scale-item reduced the internal reliability of its dimension.

\subsection{Measurement model}

An examination of the measurement model through confirmatory factor analysis showed our hypothesized factor structure, for both the place meanings scale and the desired outcomes scale, fit the data well. The fit indices for the measurement model are displayed in panel $\mathrm{A}$ of Table 2 . We also include the fit indices for the model calculated with the data from each sample individually. For all of the measurement models, the relative chi-square and RMSEA indicate model configuration fits the data well.

Measurement and covariance invariance were tested next to assess the generalizability of model configuration. Because data came from three distinct study areas, we tested for invariance across each of the samples. First, the fit of the baseline configural model was estimated and is shown in panel B of Table 2. Given that all fit indices were acceptable, we next constrained factor loadings and intercepts to be equal across the samples and re-estimated model fit. The change in CFI was minimal $(<0.01)$ indicating measurement invariance across the samples. More simply, we can now be confident the scale-items are measuring the same constructs for each sample. Next, we added the additional constraint of setting the covariances between latent constructs to be equal across samples and re-estimated model fit. Again, the change in CFI was minimal indicating the relationships between latent constructs are invariant across samples.

\subsection{Structural model}

We next added the structural paths to the model. The resulting model fit indices for the pooled sample as well as each sample estimated independently are shown in panel $\mathrm{C}$ of Table 2. After removing non-significant parameters for the pooled model, the relative chi-square was acceptable following Schumacker and Lomax's (2004) criteria of 5 or less; the RMSEA was also acceptable (between 0.06 and 0.08 ). These indices show our hypothesized structural model provides an acceptable fit to the data. Subsequently, we tested for model invariance by constraining factor loadings and intercepts to be equal across groups. The resulting fit indices $(\Delta \mathrm{CFI} \leq 0.01)$ reveal the same latent constructs are being measured across samples. Subsequently, we constrained the structural paths to be equal across samples and re-estimating model fit. The resulting CFI of 0.85 suggest the structural paths between latent 
Table 2

Confirmatory factor analysis fit statistics.

\begin{tabular}{|c|c|c|c|c|c|c|c|c|}
\hline & $\chi^{2}$ & $d f$ & $\chi^{2} / d f$ & RMSEA [90\% C.I.] & AIC & ECVI [90\% C.I.] & CFI & IFI \\
\hline \multicolumn{9}{|l|}{ Panel A: CFA model fit } \\
\hline Pooled sample & 3627.14 & 1041 & 3.48 & $0.06[0.06-0.06]$ & 3897.14 & $6.13[5.85-6.42]$ & 0.89 & 0.89 \\
\hline Lake Shelbyville & 2127.51 & 1041 & 2.04 & $0.07[0.07-0.07]$ & 2397.51 & $11.31[10.71-11.95]$ & 0.86 & 0.86 \\
\hline Carlyle Lake & 2308.49 & 1041 & 2.22 & $0.07[0.07-0.08]$ & 2578.49 & $11.62[11.01-12.26]$ & 0.85 & 0.85 \\
\hline Navigation Project & 2625.70 & 1041 & 2.52 & $0.09[0.08-0.09]$ & 2895.70 & $14.48[13.74-15.25]$ & 0.84 & 0.84 \\
\hline \multicolumn{9}{|c|}{ Panel B: invariance tests of measurement model between samples } \\
\hline Multi-group configural model & 7061.84 & 3123 & 2.26 & $0.05[0.04-0.05]$ & 7871.84 & $12.42[12.04-12.81]$ & 0.85 & 0.85 \\
\hline Multi-group test of measurement invariance & 7196.11 & 3193 & 2.25 & $0.04[0.04-0.05]$ & 7866.11 & $12.41[12.03-12.80]$ & 0.84 & 0.84 \\
\hline Multi-group test of covariance invariance & 7495.54 & 3291 & 2.28 & $0.05[0.04-0.05]$ & 7969.54 & $12.57[12.18-12.97]$ & 0.84 & 0.84 \\
\hline \multicolumn{9}{|l|}{ Panel C: structural model fit } \\
\hline Pooled sample & 3534.96 & 1014 & 3.49 & $0.06[0.06-0.07]$ & 3858.96 & $6.07[5.79-6.36]$ & 0.90 & 0.90 \\
\hline Lake Shelbyville & 2094.05 & 1014 & 2.07 & $0.07[0.07-008]$ & 2418.05 & $11.41[10.81-12.04]$ & 0.86 & 0.86 \\
\hline Carlyle Lake & 2266.67 & 1014 & 2.24 & $0.08[0.07-0.08]$ & 2590.67 & $11.67[11.07-12.31]$ & 0.85 & 0.85 \\
\hline Navigation Project & 2558.17 & 1014 & 2.52 & $0.09[0.08-0.09]$ & 2882.17 & $14.41[13.69-15.18]$ & 0.84 & 0.85 \\
\hline \multicolumn{9}{|c|}{ Panel D: invariance tests of structural model between samples } \\
\hline Multi-group configural model & 6936.22 & 3042 & 2.28 & $0.05[0.04-0.05]$ & 7908.22 & $12.47[12.10-12.86]$ & 0.85 & 0.85 \\
\hline Multi-group test of measurement invariance & 7065.94 & 3112 & 2.27 & $0.05[0.04-0.05]$ & 7897.94 & $12.46[12.08-12.85]$ & 0.85 & 0.85 \\
\hline Multi-group test of structural invariance & 7192.23 & 3196 & 2.25 & $0.05[0.04-0.05]$ & 7856.23 & $12.39[12.01-12.79]$ & 0.85 & 0.85 \\
\hline
\end{tabular}

constructs are invariant across all three samples. Stated differently, the strength and directionality of the beta weights between latent constructs were equivalent between samples.

\subsection{The effect of place meanings on desired management outcomes}

Given the structural model provides an adequate fit to the data and is invariant across samples, we can draw inferences about the relationship between each of the place meaning factors and the desired management outcome constructs. Structural model coefficients along with their associated standard errors are presented in Table 3. Results are presented for the structural model estimated with the pooled sample. The following relationships were significant:

\subsubsection{Desired ecological outcomes}

Individuals' desire for the resource area to produce positive ecological outcomes was significantly related to their belief the resource contributed to the local community's identity $(\beta=0.25$, $p=0.003$ ) as well as the belief the resource contributed to the health of the local environment $(\beta=0.14, p=0.050)$.

\subsubsection{Desired economic outcomes}

Individuals' desire for the resource to produce desirable economic outcomes was significantly and positively related to their belief the resource contributed to the local community's identity $(\beta=0.34, p<0.001)$ and their belief the resource played a relatively large role in the region's economic health $(\beta=0.17, p=0.043)$. Alternatively, the desire to see the resource area produce desired economic outcomes was negatively related to individuals' belief that the resource contributed to local ecosystem health $(\beta=-0.18$, $p=0.009$ ).

\subsubsection{Desired lifestyle outcomes}

The desire for the resource to continue to maintain desirable lifestyles was positively and significantly related to individuals' belief the resource allowed them to express who they truly are (individual identity) $(\beta=0.24, p=0.010)$ and their belief that the resource contributed to the local community's identity $(\beta=0.36$, $p<0.001)$.

\subsubsection{Desired quality of life outcomes}

Individuals' desire for resource management to increase the quality of life of local residents was significantly influenced by the belief the resource area contributed to the community's identity $(\beta=0.36, p \leq 0.001)$.

\subsubsection{Desired sense of physical space outcomes}

The desire for resource management to actively attempt to conserve the local community's distinct physical characteristics was significantly and positively influenced by individuals' belief the resource area contributed to the local community's identity $(\beta=0.45, p \leq 0.001)$ and that the area provided a distinct place for respondent's to be themselves ( $\beta=0.19, p=0.035$ ). Conversely, the desire to see management focus on preserving the community's distinct physical characteristics was negatively influenced by respondents' dependence on the area to provide specific recreation settings $(\beta=-0.15, p=0.040)$.

\subsubsection{Desired social solidarity outcomes}

Finally, the desire for resource management to focus on providing the opportunity for individuals to develop a sense of within-group solidarity was positively related to respondents' belief the managed resource area contributed to the local community's identity $(\beta=0.42, p \leq 0.001)$.

\section{Discussion}

\subsection{Summary}

The primary purpose of this research was to examine how various place meanings affect desired management outcomes. We have suggested that increased attention on the relationships between place meanings and desired management outcome is warranted given the effects that the two processes of devolution and globalization have had on resource management. Adopting a cognitive approach, we note some of the key drivers of how individuals would like to see a resource managed are the distinct types of meanings they associate with the landscape. We tested this guiding hypothesis with data collected from residents living near three managed resource areas in the Midwestern United States. As evidenced through the relatively large amount of variance explained (0.11-0.22) in each of the desired management outcomes, we find support for the hypothesis that desired management outcomes are influenced by place meanings (Table 3 ). Further support for this hypothesis was found as our hypothesized structural model proved to be invariant across three distinct samples (panel C of Table 2). In the discussion that follows, we examine the relationships among specific place meanings and desired management outcomes. 
Table 3

Structural model coefficients.

\begin{tabular}{|c|c|c|c|c|}
\hline Dependent variable (community benefits) & Predictor (place meanings) & $\beta$ & $S E$ & $p$ \\
\hline \multirow[t]{7}{*}{ Ecological outcomes } & Individual identity & -0.02 & 0.12 & 0.900 \\
\hline & Family identity & 0.01 & 0.12 & 0.967 \\
\hline & Self efficacy & -0.11 & 0.08 & 0.170 \\
\hline & Self expression & 0.13 & 0.10 & 0.208 \\
\hline & Community identity & 0.25 & 0.08 & 0.003 \\
\hline & Economy & -0.09 & 0.09 & 0.354 \\
\hline & Ecological integrity & 0.14 & 0.06 & 0.050 \\
\hline$R^{2}$ of dependent variable & & 0.11 & & \\
\hline \multirow[t]{7}{*}{ Economic outcomes } & Individual identity & -0.08 & 0.11 & 0.479 \\
\hline & Family identity & 0.07 & 0.11 & 0.528 \\
\hline & Self efficacy & -0.15 & 0.07 & 0.046 \\
\hline & Self expression & 0.13 & 0.09 & 0.149 \\
\hline & Community identity & 0.34 & 0.08 & 0.000 \\
\hline & Economy & 0.17 & 0.09 & 0.043 \\
\hline & Ecological integrity & -0.18 & 0.07 & 0.009 \\
\hline$R^{2}$ of dependent variable & & 0.18 & & \\
\hline \multirow{7}{*}{ Lifestyle (behavioral) outcomes } & Individual identity & -0.08 & 0.11 & 0.481 \\
\hline & Family identity & -0.09 & 0.11 & 0.397 \\
\hline & Self efficacy & -0.04 & 0.07 & 0.554 \\
\hline & Self expression & 0.24 & 0.09 & 0.010 \\
\hline & Community identity & 0.36 & 0.08 & 0.000 \\
\hline & Economy & 0.08 & 0.08 & 0.351 \\
\hline & Ecological integrity & -0.13 & 0.07 & 0.053 \\
\hline$R^{2}$ of dependent variable & & 0.17 & & \\
\hline \multirow[t]{7}{*}{ Quality of life (general) outcomes } & Individual identity & 0.08 & 0.10 & 0.452 \\
\hline & Family identity & -0.11 & 0.10 & 0.302 \\
\hline & Self efficacy & -0.10 & 0.07 & 0.130 \\
\hline & Self expression & 0.16 & 0.09 & 0.061 \\
\hline & Community identity & 0.36 & 0.07 & 0.000 \\
\hline & Economy & -0.06 & 0.08 & 0.460 \\
\hline & Ecological integrity & -0.05 & 0.06 & 0.422 \\
\hline$R^{2}$ of dependent variable & & 0.16 & & \\
\hline \multirow[t]{7}{*}{ Sense of physical space outcomes } & Individual identity & -0.07 & 0.11 & 0.529 \\
\hline & Family identity & -0.02 & 0.11 & 0.836 \\
\hline & Self efficacy & -0.15 & 0.07 & 0.040 \\
\hline & Self expression & 0.19 & 0.09 & 0.035 \\
\hline & Community identity & 0.45 & 0.08 & 0.000 \\
\hline & Economy & 0.05 & 0.08 & 0.538 \\
\hline & Ecological integrity & -0.07 & 0.07 & 0.298 \\
\hline$R^{2}$ of dependent variable & & 0.22 & & \\
\hline \multirow[t]{7}{*}{ Social solidarity outcomes } & Individual identity & 0.05 & 0.11 & 0.635 \\
\hline & Family identity & 0.01 & 0.11 & 0.905 \\
\hline & Self efficacy & -0.10 & 0.07 & 0.170 \\
\hline & Self expression & 0.09 & 0.09 & 0.301 \\
\hline & Community identity & 0.42 & 0.08 & 0.000 \\
\hline & Economy & 0.03 & 0.08 & 0.689 \\
\hline & Ecological integrity & -0.12 & 0.07 & 0.085 \\
\hline$R^{2}$ of dependent variable & & 0.22 & & \\
\hline
\end{tabular}

$p$-values $<0.05$ in bold.

Across all of the significant relationships found (Table 3), only one place meaning construct was a significant and positive predictor of all desired management outcomes-community identity. Believing the resource contributes to the local community identity is significantly and positively related to each of the possible management outcomes. Previous research has linked individual identity to concern and involvement in management actions (e.g., Bricker, 1998; Smaldone, 2002). However, this line of research has not been extended to explore the link with community identity. Our results suggest that, across the range of potential management outcomes, individuals who believe the resource contributes to their local community identity are more likely to want to see the landscape managed in a way that continues to preserve that identity. It would seem entirely likely that individuals who believe the resource contributes to their local community identity would also be more likely to be involved in resource management decisions and more cognizant of how the management of those areas affects that perceived community identity. These points remain possible avenues for future research.

Our analysis also revealed that if individuals thought the resource provided them with a place where they could express themselves, they were more likely to want to see the resource managed for desirable lifestyle and quality of life outcomes. This finding lends support for the idea that those individuals who use the resource as a creative or recreational outlet are more likely to value the resource for the contribution it makes to their lifestyle and perceived quality of life. Previous scholarship, primarily focused on recreationists, has shown a direct and positive link between individual identity and preferences for management outcomes (e.g., Kyle et al., 2003; Vogt \& Williams, 1999) without defining the subtle difference between place identity and self-efficacy. It is possible, given the evidence found in this research, that the differentiation between the two constructs could play a key role in understanding how individuals' preferences for management actions are formed. Individuals who endow a space with meaning because that space allows them to express themselves may be more likely to support management decisions and become involved in collaborative planning and management if they believe management is actively seeking to preserve local lifestyles and the quality of life of local residents.

Several of the findings from the analysis were expected. It seems intuitive that if individuals believe the resource area plays 
a major role in contributing to the health of the local environment, those individuals would be more likely to want to see the area managed for desired ecological outcomes in the future; this turned out to be the case. Similarly, individuals who believe the resource plays a large role in the region's economic health should also want the area to be explicitly managed to produce continued economic benefits; this also proved to be the case.

Several place meanings had a negative influence on desired management outcomes. These findings highlight a unique aspect of the research. Most research which relates place meanings to management actions has not differentiated between (i) what types of place meanings individuals hold (most frequently the differentiation is simply between 'place identity' and 'place dependence') or (ii) management actions that focus on different outcomes (most research simply focuses on concern for management actions). Our approach allows for some of the contradictions to be seen between distinct types of place meanings and distinct types of management outcomes. Specifically, we found individuals who believed the resource played an important role in the protection of the local environment were less likely to want to see the area managed for economic outcomes. This finding suggests that residents perceive ecosystem conservation and economic development to form a dialectic relationship. A negative relationship was also found between individuals' belief the resource played an important role in local environmental protection and their desire to see the resource managed to produce feelings of within group solidarity. This finding suggests respondents do not necessarily see ecosystem conservation as a prerequisite for greater feelings of social togetherness. Finally, the results reveal that stronger feelings of individual resource dependency (self-efficacy), most likely originating from particular recreational activities the resource area facilitates, are negatively related to the desire to see the resource managed for either a sense of physical space or ecological outcomes. The latter finding is expected (no theoretical reason links resource dependency and the physical characteristics of the local community), however the former is not. One might expect individuals who need the resource area to facilitate specific activities would want management to focus on maintaining the health of the local environment; this would be consistent with the Dunlap-Heffernan thesis (see Theodori, Luloff, \& Willits, 1998). Apparently for our sample, however, respondents perceived no connection between their ability to engage in desired activities while at the resource area and the ecological health of the surrounding landscape.

\subsection{Conclusion}

The role of place meanings in landscape management, and particularly public lands management has grown over the past few decades. The increased importance of 'place' in resource management can partly be attributable to devolution and globalization, which have simultaneously pushed decision making capabilities to more local levels and caused individuals to place greater value on the uniqueness of their communities and the environments in which they are embedded. In this research we have explored how the meanings residents of a 'regional working landscape' attach to space affect their preferences for resource management outcomes. Implicit in our questioning has been the assumption that resource managers must consider more than just the implications their decisions can have on the resource itself. Rather, resource management must now consider local communities and their residents as integral parts of the local ecosystem (Brandenburg \& Carroll, 1995; Eisenhauer, Krannich, \& Blahna, 2000; Williams et al., 1992). Most federal land management agencies are explicitly mandated to consider both the ecological and social impacts their actions can have. Consequently, understanding the meanings local residents attach to resource areas can assist in 'bridging the gap between ecosystem science and management' (Williams \& Stewart, 1998, p. 18). A complex set of relationships exists between how individuals ascribe value to managed landscapes and how they would like to see them managed. This research begins to unravel some of these complexities. Continued efforts directed at understanding how distinct meanings ascribed to natural landscapes affect management preferences can assist managers and resource planners in serving local communities and, ultimately, developing a shared future sense of place.

\section{Acknowledgements}

This research was funded through a cooperative agreement with the U.S. Army Corps of Engineers, which was facilitated by the Great Lakes - Northern Forests CESU. The authors would also like to thank Dr. Ronald Wimberley for his notes and comments. 


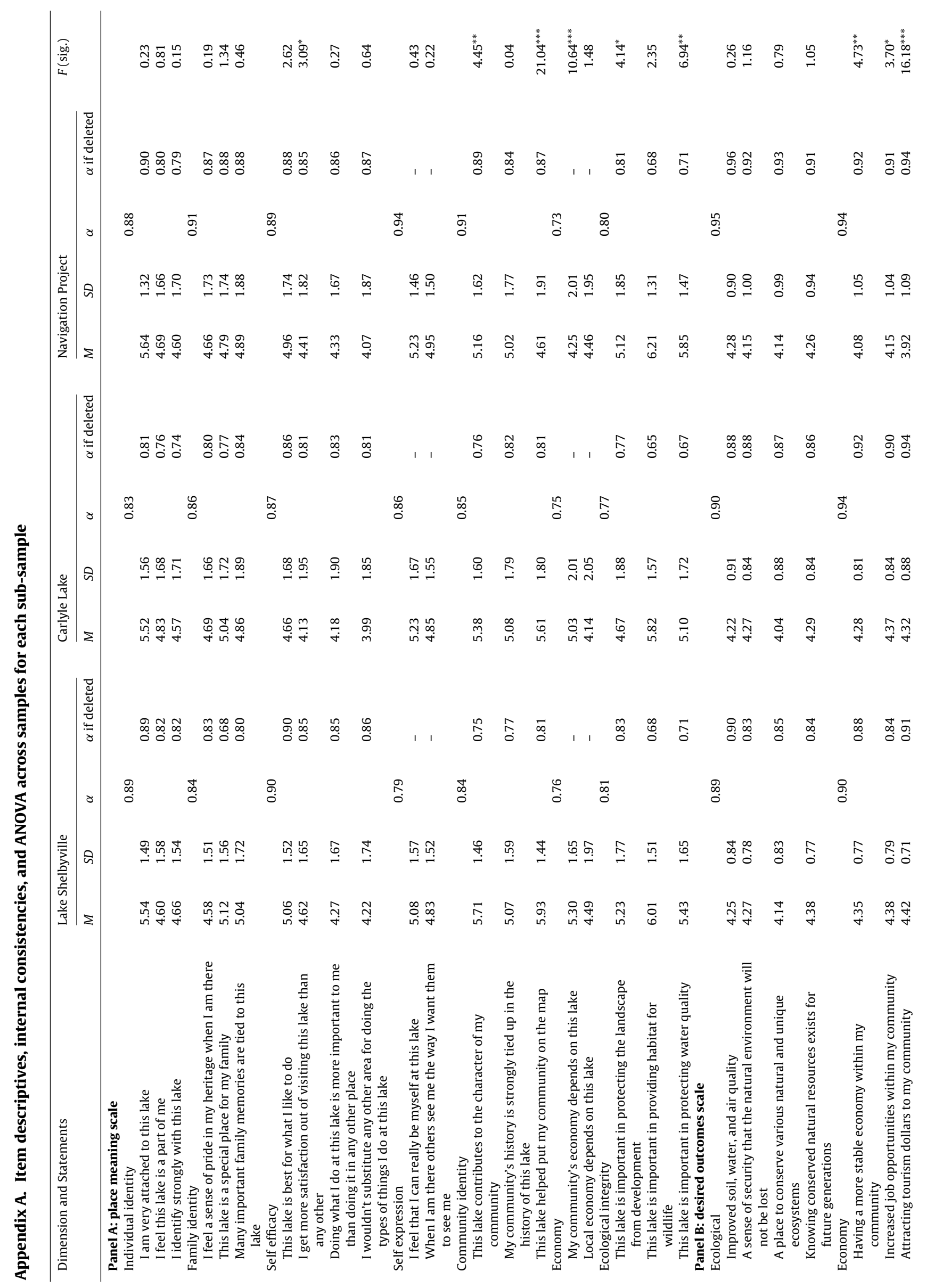




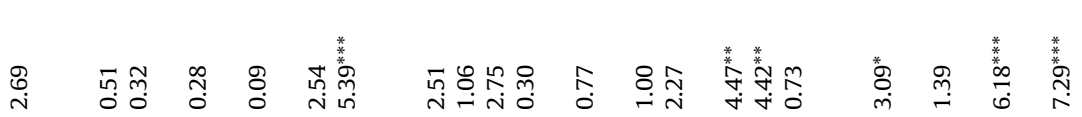
ด.

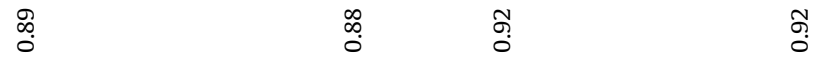

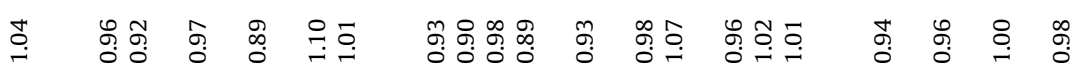

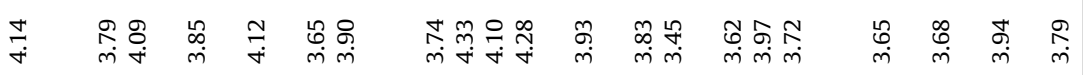

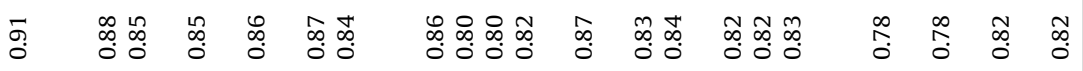
$\begin{array}{llll}\infty & \infty & \infty & \infty \\ \infty & 0 & \infty & 0 \\ 0 & \infty & 0\end{array}$

䓦

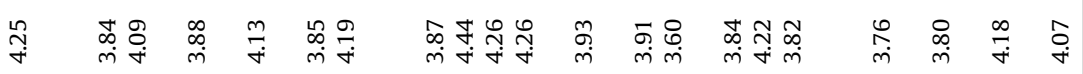
品 $\begin{array}{llll}\infty & \infty & \infty \\ 0 & \infty & \infty & \infty \\ 0 & \infty & \infty & \infty\end{array}$

苜

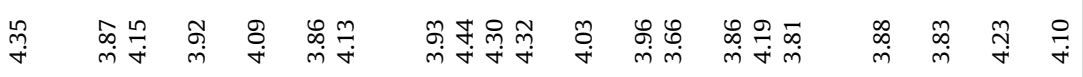

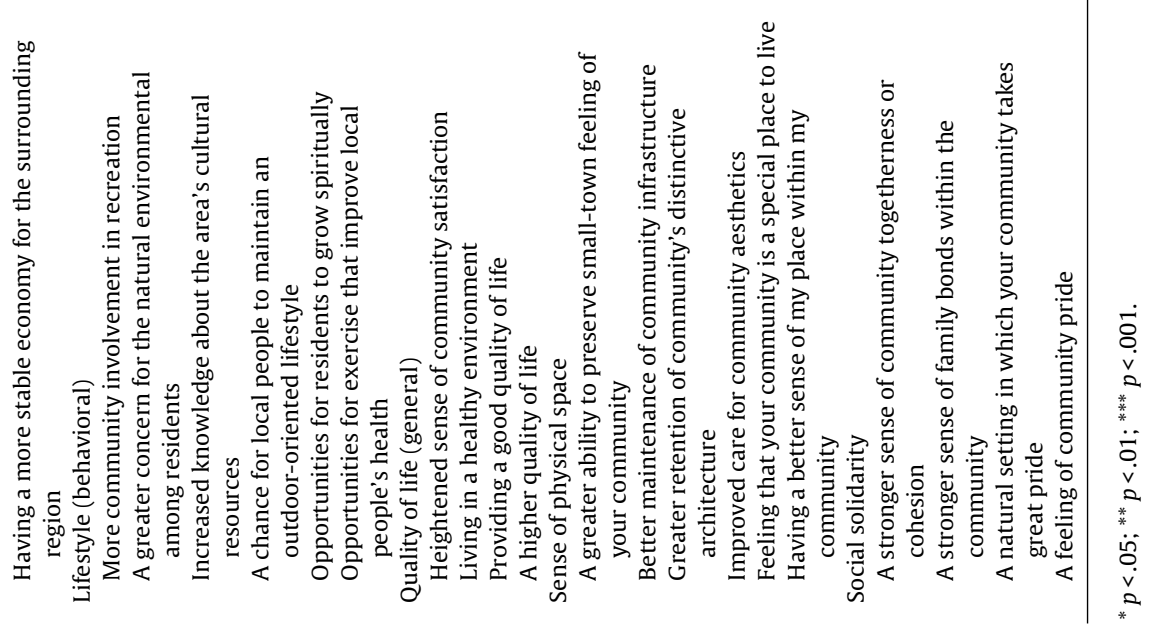




\section{References}

Agnew, J. A., \& Duncan, J. S. (1989). The power of place: Bringing together geographical and sociological imaginations. Boston, MA: Unwin Hyman.

Anderson, D. H., Davenport, M. A., Leahy, J. E., \& Stein, T. V. (2008). OFM and community benefits. In B. L. Driver (Ed.), Managing to optimize the beneficial outcomes of recreation (pp. 311-334). State College, PA: Venture.

Armstrong, J. S., \& Overton, T. S. (1977). Estimating nonresponse bias in mail surveys. Journal of Marketing Research, 14(3), 396-402.

Boden, D., \& Molotch, H. (1994). The compulsion of proximity. In R. Friedland, \& D Boden (Eds.), Nowhere: Space, time and modernity (pp. 257-286). Berkeley, CA: University of California Press.

Brandenburg, A. M., \& Carroll, M. S. (1995). Your place or mine? The effect of place creation on environmental values and landscape meanings. Society $\mathcal{E}$ Natural Resources, 8, 381-398.

Bricker, K. (1998). Place and preference: A study of whitewater recreationists on the South Fork of the American River. Unpublished doctoral dissertation, The Pennsylvania State University Press, State College, PA.

Burnett, P. (1976). Behavioral geography and the philosophy of the mind. In R. G. Golledge, \& G. Rushton (Eds.), Spatial choice and spatial behavior: Geographic essays on the analysis of preferences and perceptions (pp. 23-48). Columbus, $\mathrm{OH}$ The Ohio State University Press.

Canter, D. (1977). The psychology of place. Columbus, OH: St. Martin's Press.

Cheng, A. S., Kruger, L. E., \& Daniels, S. E. (2003). "Place" as an integrating concept in natural resource politics: Propositions for a social science research agenda. Society \& Natural Resources, 16, 87-104.

Cheung, G.W., \& Rensvold, R. B. (2002). Evaluating goodness-of-fit indexes for testing measurement invariance. Structural Equation Modeling, 9, 233-255.

Davenport, M. A. (2003). Mixing metaphors: A community-based vision for the Niobrara National Scenic River. Unpublished doctoral dissertation, University of Minnesota, St. Paul, MN.

Davenport, M. A. (2006). A conceptual overview of an integrative place dependence scale. Paper presented at the International Symposium on Society and Resource Management.

Davenport, M. A., \& Anderson, D. H. (2005). Getting from sense of place to place based management: An interpretive investigation of place meanings and perceptions on landscape change. Society \& Natural Resources, 18(7), 625-641.

Davenport, M. A., Baker, M. L., Leahy, J. E., \& Anderson, D. H. (2010). Exploring multiple meanings at an Illinois State Park. Journal of Park and Recreation Administration, 28(1), 52-69.

Dillman, D. A. (2007). Mail and internet surveys: The tailored design method (2nd ed.) New York: John Wiley \& Sons.

Dunlap, R. E., \& Mertig, A. G. (1991). The evolution of the United-States environmental movement from 1970 to 1990: An overview. Society E Natural Resources, 4(3), 209-218.

Eisenhauer, B. W., Krannich, R. S., \& Blahna, D. J. (2000). Attachment to special places on public lands: An analysis of activities, reasons for attachments, and community connections. Society \& Natural Resources, 13, 421-441.

Golden, M. M. (1998). Interest groups in the rule-making process: Who participates? Whose voices get heard? Journal of Public Administration Research and Theory, $8(2), 245-270$

Greider, T., \& Garkovich, L. (1994). Landscapes: The social construction of nature and the environment. Journal of Environmental Psychology, 21, 273-281.

Harvey, D. (1993). From space to place and back again: Reflections on the condition of post-modernity. In J. Bird, B. Curtis, T. Putnam, G. Robertson, \& L Tickner(Eds.) Mapping the futures: Local cultures, global change (pp. 3-29). London: Routledge.

Harvey, D. (1996). Justice, nature and the geography of difference. Malden, MA: Oxford and Blackwell.

Hu, L., \& Bentler, P. M. (1999). Cutoff criteria for fit indexes in covariance structure analysis: Conventional criteria versus new alternatives. Structural Equation Modeling, 6(1), 1-55.

Hunter, L. M., Boardman, J. D., \& Saint Onge, J. M. (2005). The association between natural amenities, rural population growth, and long-term residents' economic well-being. Rural Sociology, 70(4), 452-469.

Kline, R. B. (2005). Principles and practices of structural equation modeling (2nd ed.). New York: Guilford.

Koontz, T. M., Steelman, T. A., Carmin, J., Korfmacher, K. S., Moseley, C., \& Thomas, C. W. (2004). Collaborative environmental management: What role for government? Washington, DC: Resources for the Future.

Kruger, L. E. (2001). What is essential may be invisible to the eye: Understanding the role of place and social learning in achieving sustainable landscapes. In S. R. J. Sheppard, \& H. W. Harshaw (Eds.), Forests and landscapes: Linking ecology, sustainability, and aesthetics (pp. 173-188). New York: CABI

Kruger, L. E. (2008). An introduction to place-based planning. In: J. O. Farnum, \& L. E. Kruger, (Eds.), Place-based planning: Innovations and applications from four western forests. Gen. Tech. Rep. PNW-GTR-741 (pp. 1-6). Portland, OR: U.S Department of Agriculture, Forest Service, Pacific Northwest Research Station.

Kruger, L. E., \& Jakes, P. J. (2003). The importance of place: Advances in science and application. Forest Science, 49(6), 819-821.

Kruger, L. E., \& Shannon, M. A. (2000). Getting to know ourselves and our places through participation in civic social assessment. Society $\mathcal{E}$ Natural Resources, 13(5), 461-478.
Kruger, L. E., Williams, D. R. (2007). Place and place-based planning. In: L. E. Kruger R. Mazza, \& K. Lawrence, (Eds.), Proceedings: National workshop on recreation research and management. Gen. Tech. Rep. PNW-GTR-698 (pp. 83-88). Portland OR: U.S. Department of Agriculture, Forest Service, Pacific Northwest Research Station.

Kyle, G. T., Absher, J. D., \& Graefe, A. R. (2003). The moderating role of place attachment on the relationship between attitudes toward fees and spending preferences. Leisure Sciences, 25, 33-50.

Kyle, G. T., Graefe, A. R., \& Manning, R. E. (2005). Testing the dimensionality of place attachment in recreation settings. Environment and Behavior, 37, 153177.

Leahy, J.E., \& Anderson, D. H. (2010). Cooperation gets it done": Social capital in natural resources management along the Kaskaskia River. Society \& Natural Resources, 23(3), 224-239.

Lobao, L. (2004). Continuity and change in place stratification: Spatial inequality and middle-range territorial units. Rural Sociology, 69(1), 1-30.

Low, S. M., \& Altman, I. (1992). Place attachment: A conceptual inquiry. In I. Altman, \& S. M. Low (Eds.), Place attachment (pp. 1-12). New York: Plenum Press.

Mander, J., \& Goldsmith, E. (Eds.). (1996). The case against the global economy: And for a turn toward the local. San Francisco, CA: Sierra Club Books.

Meyer, J. W., Boli, J., Thomas, G. M., \& Ramirez, F. O. (1997). World society and the nation-state. American Journal of Sociology, 103(1), 144-181.

Moore, G. T. (1976). Theory and research on the development of environmenta knowing. In G. T. Moore, \& G. T. Golledge (Eds.), Environmental knowing: Theories, research, and methods (pp. 138-164). Stroudsburg, PA: Dowden, Hutchinson \& Ross.

Proshansky, H. M., Fabian, A. K., \& Kaminoff, R. (1995). Place identity: Physical world socialization of the self. In L. Groat (Ed.), Giving places meaning: Readings in environmental psychology (pp. 87-113). London: Academic Press.

Relph, E. (1976). Place and placelessness. London: Pion.

Schumacker, R. E., \& Lomax, R. G. (2004). A beginner's guide to structural equation modeling (2nd ed.). New York: Psychology Press.

Shamai, S. (1991). Sense of place: An empirical measurement. Geoforum, 22(3), 347-358.

Sharp, J. S., \& Parisi, D. M. (2003). Devolution: Who is responsible for rural America? In D. L. Brown, \& L. E. Swanson (Eds.), Challenges for rural America in the twenty-first century (pp. 353-362). University Park, PA: The Pennsylvania State University Press.

Smaldone, D. (2002). An exploration of place attachment in Jackson Hole, WY. Moscow, ID: University of Idaho., $157 \mathrm{pp}$.

Smith, J. W., Anderson, D. H., Davenport, M. A., \& Leahy, J. E. (2010). Perceived community benefits from recreation resources: From scale development to validation. In Proceedings of the Northeastern Recreation Research Symposium April 11-13, Bolton Landing, NY.

Stedman, R. C. (2003). Sense of place and forest science: Toward a program of quantitative research. Forest Science, 49(6), 822-829.

Theodori, G. L., Luloff, A. E., \& Willits, F. K. (1998). The association of outdoor recreation and environmental concern: Reexamining the Dunlap-Heffernan thesis. Rural Sociology, 63(1), 94-108.

Tickamyer, A. R. (2000). Space matters! Spatial inequality in future sociology. Contemporary Sociology, 29(6), 805-813.

Trentelman, C. K. (2009). Place attachment and community attachment: A primer grounded in the lived experience of a community sociologist. Society \& Natural Resources, 22(3), 191-210.

Tuan, Y. F. (1974). Topophilia: A study of environmental perception, attitudes, and values. Englewood Cliffs, NJ: Prentice Hall.

U.S. Department of Agriculture. (2010). Strategic plan FY 2010-2015. Washington, DC: U.S. Department of Agriculture.

U.S. Department of the Interior. (2011). Strategic plan for fiscal years 2011-2015. Washington, DC: U.S. Department of the Interior.

Vogt, C. A., \& Williams, D. R. (1999). Support for wilderness recreation fees: The influence of fee purpose and day versus overnight use. Journal of Park and Recreation Administration, 17(3), 85-99.

Warner, M. E. (2003). Competition, cooperation, and local governance. In D. L. Brown, \& L. E. Swanson (Eds.), Challenges for rural America in the twenty-first century (pp. 252-261). University Park, PA: The Pennsylvania State University Press.

White, D. D., Virden, R. J., \& van Riper, C. J. (2008). Effects of place identity, place dependence, and experience-use history on perceptions of recreation impacts in a natural setting. Environmental Management, 42(4), 647-657.

Wilkinson, K. P. (1991). The community in rural America. Westport, CT: Greenwood Press.

Williams, D. R. (2002). Leisure identities, globalization, and the politics of place. Journal of Leisure Research, 34(4), 351-367.

Williams, D. R., Patterson, M. E., Roggenbuck, J. W., \& Watson, A. E. (1992). Beyond the commodity metaphor: Examining emotional and symbolic attachment to place. Leisure Sciences, 14(1), 29-46.

Williams, D. R., \& Stewart, S. I. (1998). Sense of place: An elusive concept that is finding a home in ecosystem management. Journal of Forestry, 96(5), 18-23.

Williams, D. R., \& Vaske, J. J. (2003). The measurement of place attachment: Validity and generalizability of a psychometric approach. Forest Science, 49(6), 830840. 